\title{
Micro-Physics of Discipline: Spaces of the Self in Middle Eastern Women Life Writings
}

\author{
https://doi.org/10.33806/ijaes2000.20.2.12 \\ Moussa Pourya Asl \\ Universiti Sains Malaysia, Malaysia
}

\begin{abstract}
Contemporary life narratives by or about Middle Eastern women often portray the female body as the object of oppressive ethical and political governmentalities. This article focuses on the writings of a generation of secular and Muslim women, whose works describe the condition of women as subjugated by sovereign states and disciplinary governments, to examine the politics of space in the workings of the complex interactions between gender and power. To this end, Erving Goffman's spatial theories on the territories of the self and the modalities of contamination are used to examine the function of political spaces in Jean P. Sasson's Princess, Azar Nafisi's Reading Lolita in Tehran, Zainab Salbi's Between Two Worlds, and Manal al-Sharif's Daring to Drive. The findings indicate that three modes of violations strategically contaminate the female subjects' spaces of the self: informational preserve, physical and interpersonal. Of all the three modes, physical contamination - such as mandatory veiling/deveiling, corporeal exposure, forced exposure to dirt and appropriation of personal possessions-proves to be the most common. The study concludes that even though space is used as a strategy of regulating the female body, the subjugated women constantly struggle to re-construct different spaces to disrupt the flow of contamination.
\end{abstract}

Keywords: Azar Nafisi, contamination of space, female body, Jean P. Sasson, , Manal alSharif, Zainab Salbi

\section{Introduction}

Foucault's (1980: 149; 1986: 23) notion of the "political technology of the body" and his understanding of the present era as the "epoch of space" are important in the context of the portrayal of female bodies by contemporary life writings of Middle Eastern women. When describing women's everyday life experiences in the region, many of the recent narratives depict female bodies as objects of oppressive ethical and political governmentalities that foster their compliance with the patriarchal socio-political normativities (Grogan 2014:59). Several of the existing life narratives describe a disciplinary system of subjugation whereby the female body is the primary target of microphysics of power. Such a heavy emphasis on the image of an innocent female body and its physical abuses sexualizes the experience of existing regimes of power because the images make a powerful analogy between life in the Middle East and the sexual domination of women. Undoubtedly, women's subjugation by sovereign states and disciplinary 
governments in the Middle East is not caused in any undemanding and simple way by "men's possession of power" (Batmanghelichi 2017:5), but by more complex forms of the interface between institutions and bodies that take place in various spaces. Discipline, as Foucault (1995:141) explains, "proceeds from the distribution of individuals in space," operates by regimentation of space and time, albeit not automatically but by strategically denying subjects the "access to the various kinds of spaces required for one to manage and define one's self' [italics not mine] (Leib 2017:192). Deprived of these spaces, the subject is re-formulated as merely a "function of the institution" with an increased level of compliance.

This article aims to explore some of the recent eyewitness accounts by or about Middle Eastern women to examine the different spaces for the complex interactions between gender and power. To this end, it focuses on the writings of a generation of secular and Muslim women whose (privileged) social and political statuses have been denied in their contemporary patriarchal societies. The Saudi princess Sultana's life story in Princess: A True Story of Life Behind the Veil in Saudi Arabia (1992), the Iranian memoirist Azar Nafisi's Reading Lolita in Tehran (2003), the Iraqi life writer Zainab Salbi's Between Two Worlds Escape from Tyranny: Growing up in the Shadow of Saddam (2005), and the Saudi social activist Manal al-Sharif's Daring to Drive (2017) recount original and similar observations about "traumatic or harrowing personal experiences" of women living in male-centered, discriminatory societies (Naghibi 2017:176). All the four narratives present the female body as entangled in a system of subjection that forces on it particular impositions like veiling or deveiling. In that, the works address issues of hegemony, ideology and governmentality which make use of different spaces to reshape female subjects' identities.

Erving Goffman offers a sophisticated framework for understanding the normalizing interaction practices and social relationships as portrayed in the selected works. His theories investigate the field of public life in terms of its connections with social relationships "that figure when the related persons are in one another's immediate presence" (Goffman 1971:x). Goffman's $(1956,1971)$ dramaturgical analyses in sociology, in particular his symbolic neo-interactionism, is relevant in exploring the "political spaces" and political norms as functioning in the life writings and in unraveling the nature of the female characters' subjugation in social relationships. Furthermore, Goffman's spatial concepts of "front region," "back region," and "territory of the self" offer the advantage of an interpretiveanalytical framework for examining the behavior of the perpetrator and the victim, or the subject and the object of the power alike. Notwithstanding that Goffman's subjects are primarily inmates of institutions like mental patients and prisoners, his humane viewpoint includes the idea that the territories of the self are socially determined and "the higher the rank, the greater the size of the territories of the self, the greater controls across boundaries" (Goffman 1971:40-41). ${ }^{1}$ His theories will help to identify the dramaturgical techniques that are used by those in a position within the portrayed regimes of power to control the conducts of the subjects, and hence to unravel the ways the subjugated women are made and unmade by the social and material forces in their daily lives. This particular focus 
on the functioning of power distinguishes the study from the widespread understanding of the works in relation to East/West binaries as the present study examines the mechanisms of power and strategies of governmentality on female bodies irrespective of the subjects' geographical localities.

Hence, in analyzing the selected narratives within the framework of a micro-physics of power, this essay expands upon recent scholarship that considers the memoirists as a problematic subject of resistance from the standpoint of radical political traditions. To explore the life writings, as private archives of situation of women in the Middle East and their everyday subjection by the ruling governments, scholars have developed diverse theoretical and conceptual approaches-e.g., literature on the issues of gender, feminism, politics, ideology of the revolution, Orientalization, exile and trauma, to name but a few (Asl 2018:196; Asl 2019:45-46). The dominant theoretical standpoint explores the works in terms of their "opposition to hegemonic structures of power," and acclaims the ones that "offer a coherent and progressive counter-hegemonic challenge to the status quo" (Death 2016:201). Though the studies have brought into focus women's feminist struggles to subvert dominant ways of being in a political engagement with the established disciplinary modes of power (Paolucci, Holland and Williams 2005:139), the functioning of the hierarchies of power have remained unexplored. In the following section, I will review some of the existing literature in detail.

\section{Literature review}

Many contemporary Middle Eastern women life writers have been criticized as a problematic subject of resistance. By "problematic," I refer to the large body of criticism that contemptuously dismisses their autobiographical works as irrelevant or politically compromised and swiftly condemn their similar monolithic portrait of Middle Eastern women (Naghibi 2007; Batmanghelichi 2017). Dabashi (2006), for instance, takes memoirists like Nafisi as neoconservative native informers who failed to grasp the complicated social history of their countries. He argues that the works' similarly irresponsible depictions of Islamic states as essentially misogynistic is in accordance with native Orientalist discourse that makes their writings operate as "a key propaganda tool at the disposal of" the American government and its contemporary nationalist discourse of war on terror. The claim, albeit a politically radical one, is substantiated by many other critics like Ameri (2012), Bahramitash (2005), Hasan (2015) and Newns (2017) who unanimously chastise the works' biased Western perspective as particularly filled with Islamophobic rhetoric prevalent within the dominant discursive practices in the West against the countries of the region. Narrated with such Orientalist prejudice, it is claimed that the female informers' eyewitness accounts have no truthful qualities.

Ameri (2012) questions the accuracy of women's life stories, and criticizes them for their oversimplified and stereotypical depictions of women in the region. She claims that many of the works portray Islam as a primitive, "backward and violent religion" and its female followers as the passive victims of monstrous, 
sadistic men (Ameri 2012:2). Hence, the narratives comply with the contemporary Islamophobic discourse that describes the situation of women under Islamic tradition as "oppressed, abject and in need of liberation by Westerners" (Ameri 2012:61). Relatedly, Bahramitash (2005) describes the memoirists as selforientalising, neo-conservative ideologues. She (2005:221-2) criticizes both native female life writers and Western ghostwriters for their monolithic accounts of "a homogeneous category" of Middle Eastern women as subject to "misogynist state policies," arguing that their biased perspective contributes to a particular agenda-i.e., to promote Islamophobia and "to raise support for the neoconservative agenda . . . [of] the war on terror". In like manner, Hasan (2015:90) argues that the content and even the "authorial authenticity" of these writings are manipulated by Western collaborators and publishers. Hence, many of the works stereotypically show local men's monstrous and chauvinistic treatment of women, who "are perceived as passive, complicitous, submissive, silent, voiceless, invisible, waiting to be rescued by a passing Westerner" (Hasan 2015:91). Newns (2017:2) repeats the charge against "Western publishing houses," and claims that the life writings contribute to the conventional, not least the post-9/11, discourse of "a homogeneous world of veiled and oppressed Muslim women in need of saving".

In many respects, such condemnation of the works' "truthful" representation - which is the common epithet the women in question use in the Author's Note of their respective books to characterize the objective nature of their stories - is warranted. Throughout the narratives, the writers repeatedly express anti-Muslim sentiments and fail to show understanding of or empathy for the majority of Muslim women who truly practice and respect their religion and cultural traditions. This is particularly true of Jean P. Sasson whose sensational and questionable ethnographic documents on the plight of women "under Islam and Islamic terror" appear to serve a U.S. agenda in the Middle East (Chan-Malik 2011:115). The stereotyping patterns of rape by Muslim men of Middle Eastern women throughout her works reinforce the pre-existing American "racialorientalist 'discourse of the veil,' in which 'Islam' was rendered a national catchphrase for terror" and which has been "deployed to justify U.S. military aggression" in the region (Chan-Malik 2011:112). That said, this essay does not seek to participate in reduction of the writers to the essentialist "neo-conservative" or "Oriental feminist" discourse. This essay seeks to further understanding of the narratives with respect to the socio-political context of the region, and so it proposes a micro-physical analysis of the works to demystify a certain aspect of the functioning of disciplinary institutions with regards to the female body within the portrayed patriarchal societies. In this manner, this theoretical analysis of the female subjects' articulation of their repressed life experiences reveals the transformative capacity of writing that opens up "virtual spaces" which enable the subordinated female subjects "to engage in a potentially transformative relation with the world; to bring about that which does not exist and to transform that which does exist" (O'Leary 2008:18). In this sense, the present study becomes situated upon the postcolonial premise that Middle Eastern women writing in 
English and their female protagonists seek to create spaces of "self-fashioning" (Moore 2012, 80), of "fulfilling difference" and "personal and creative freedom," and thereby to reimagine "human community, seeking the way we can live now" (Campbell 2019:54-56).

\section{Theories of Erving Goffman on territories of the self}

Goffman (1956:69) divides the society into a "front region" and a "back region" or "backstage." While the former is the place where "accentuated facts make their appearance," the latter refers to the storehouse of "the suppressed facts". The backstage is a place where the subjugated character can temporarily escape from the social impositions, relax, "drop his front, forego speaking his lines, and step out of [the] character" fabricated for the front region (Goffman 1956:70). In describing the condition of women, Simone de Beauvoir underlines the importance of the back region for women's proper maintenance of self, contending that the backstage and its activities imply "truthfulness" among women because in the front stage "woman is always play-acting [for the male audience] . . . [and] is more or less conscious of the thought: 'I am not being myself'" (Goffman 1956:70). Hence, Goffman's division of space into the visible front and the invisible backstage is strategically vital in order for the female subject to stop her routine for short periods of relaxation, prepare for a different role on the stage, and feel in control of herself. As the secrets of the performance are kept in the privacy of the backstage, it is realistic for the (female) performer to expect that the entire territory of "back region will be kept hidden" from members of the audience. Goffman goes on to identify eight different preserves or territories as: 1) personal space; 2) the stall; 3) use space; 4) the turn; 5) the sheath; 6) possessional territory; 7) information preserve; and 8) conversational preserve.

Personal space is the prototypical spatial preserve that refers to "[t]he space surrounding an individual, anywhere within which an entering other causes the individual to feel encroached upon, leading him to show displeasure and sometimes to withdraw" (Goffman 1971:29-30). In contrast to personal space that is mainly "a one-person possession," that has "ever-shifting dimensions" and that is a culturally and situationally contingent preserve, stalls "provide external, easily visible, defendable boundaries for a spatial claim" (Goffman 1971:34). Goffman defines the stall as "[t]he well-bounded space to which individuals can lay temporary claim, possession being on an all-or-none basis" (Goffman 1971:32). Linked to both these spatial preserves is what he calls the "use space," which is "[t]he territory immediately around or in front of an individual, his claim to which is respected because of apparent instrumental needs" (Goffman 1971:34-5).

Goffman extends the notion of territoriality from an exclusive focus on spatial functions to situational and then to egocentric territoriality. Hence, a situational territoriality that he calls "the turn" is described as "[t]he order in which a claimant receives a good of some kind relative to other claimants in the situation" (Goffman 1971:35). An egocentric territoriality that co-mingles with personal space is the "sheath"-his term for the outer layer of the body, the skin, 
and the clothes. With regards to the body's sheath, different parts of the corporeal sheath - e.g. elbow, face, orifice areas-are accorded different concern, meaning that depending on the culture and the situations, "the body will be differently segmented ritually" (Goffman 1971:38). A salient aspect of this territoriality is that regardless of the interactional context, the body skin is "experienced and conceptualized as the outer boundary of self, so that the touch of an object not actually invited is an intrusion into the most intimate realm of personal space" (Allen-Collinson 2009:56). Across the Middle East, the female body is thus segmented differently. Whereas Saddam Hussein takes women's wearing a head scarf as an indication of her being "too religious" and thus her affiliation with an oppositional religious party" (Salbi 2005:80), Saudi fundamentalists command a "full veiling of the body," asserting that "the whole of the woman - her body and her voice - is a'ura (sinful to put on display) and should not be revealed unless there is a need for her to do so" (al-Sharif 2017:99).

Another egocentric territoriality in which the participant's personal territory coincides somewhat with his performance is possessional territory which is defined as: "Any set of objects that can be identified with the self and arrayed around the body wherever it is" (Goffman 1971:38). This includes any object that has "personal effects," from easily detachable possessions like jackets, hats, gloves, cigarette to objects tethered to a particular setting for temporary usage like ashtrays, magazines, eating utensils, and to regulative command over mechanical creature-comfort devices in stalls like control over radio, television sets, temperature, windows, etc.

And finally Goffman touches upon the informational and conversational preserves. With the former, he refers to "[t]he set of facts about himself to which an individual expects to control access while in the presence of others" (Goffman 1971:38-9), for example: the content of the individual's mind; the claimant's biographical information; the contents of pockets, bags, containers, emails, letters, and so forth; and last but not least, "his body's sheath" and the way he currently behaves. He defines the latter as "the right of an individual to exert some control over who can summon him into talk and when he can be summoned; and the right of a set of individuals once engaged in talk to have their circle protected from entrance and overhearing by others" (Goffman 1971:40).

Goffman maintains that a common feature of all these territories is that their variability is "socially determined," a proposition that dramatically raises the possibility of infractions upon them by others. These territories can be violated by other participants through a range of mortification practices like trespassing, touching, looking, and so forth. Goffman (1961) identifies three distinctive modalities of social contamination by others, whereby the claimed space is intruded and the individual is deprived of his territories; these include: a) violation of informational preserve; b) physical contamination; and c) interpersonal contamination. The first refers to exposure of "facts and feelings about self to new kinds of audiences" which may vary according to the type of institution for example: prison, hospital, religious institutions, and school (Goffman 1961:24). The second, which is also the clearest mode of contaminative exposure, refers to 
the "the besmearing and defiling of the body or of other objects closely identified with the self" (Goffman 1961:25). Examples cited by Goffman include: corporeal exposure during medical or security examinations; communal shower in disciplinary institutions like schools, gyms, etc.; physical stripping of clothing or vice versa as disciplinary tactics; attacks upon the sexual parts; forced contact with "dirty, sullied or defiling objects and substances" (Allen-Collinson 2009:59); exposure to "unclean food, messy quarters, soiled towels, shoes and clothing impregnated with previous users' sweat, toilets without seats, and dirty bath facilities" (Goffman 1961:26). Finally, there is demolition or concealment of one's personal possessions such as objects, creative artifacts as well as the annihilation of his symbolic possessions like creativity, skills, and talents. This mode of mortification of the self, according to Goffman, is further amplified "when the agency of contamination is another human being," which means the individual is further "contaminated by forced interpersonal contact and, in consequence, a forced social relationship" (Goffman 1961:28). Examples abound from dramatic ones such as rape and sexual molestation where the subject is coerced into incorporating the perpetrator into her/his extended self to less drastic, yet deleterious, forms like unwanted touching, exposure of one's relationships to significant others, and finally, penetration of the most private spaces of the individuals.

The primary and overt result of systematic contamination of territories of the self in disciplinary institutions is "docility" and "manageability" of the social individuals as their "resistance" or "spirit" is somehow broken. In other words, because "spatial relations are of crucial importance to one's sense of self," and the individual's control over "how to dispose of or defend these spatial claims is fundamental to her seeing herself as an autonomous, independent self," deprivation of these claims and violation of the territories, and in effect, "losing primary control over these relations would equate to a significant loss of self, from which docility becomes more likely" (Leib 2017:202-3). Hence, for Goffman, disciplinary institutions use strategic tactics and dramaturgical techniques to divest the individual of access to a true back region and in so doing not only strategically break the individual's sense of self but also effectively reduce her resistance and control her conduct. This process is very much like Foucault's account of the "automatic functioning of power" in disciplinary societies, whereby the exercise of power is perfected in a way that seems "it never intervenes, it is exercised spontaneously and without noise" (Leib 2017:204). In what follows, this essay employs Goffman's territories of the self and their contamination as a Foucauldian micro- physics of discipline to explore and demystify a particular aspect of Middle Eastern women's eyewitness accounts of lived-female-body experiences under patriarchal governments as depicted in their narratives.

\section{Social contaminations in Middle East life writings}

Throughout the selected narratives, it is shown that women experience multiple forms of physical contamination such as physical clothing, corporeal exposure, 
forced exposure to filth and nastiness, and demolition of their personal properties. Whereas Sultana, Nafisi and al-Sharif relate stories of women's subjection to mandatory veiling of their bodies, Salbi narrates tales of their forced stripping in Saddam Hussein's regime. Iraqi state law prohibited the wearing of the hijab as the regime associated women's veiling with the ideological intrusion of rival countries, in particular Iranian Shi'ite convictions. Hence, throughout the memoir, it is repeatedly shown that the government conducts surprise searches to ensure social stability by regulating irregularities. During the searches, which were carried out by the secret government agency called the Mukhabarat, "a head scarf, a prayer, a long skirt, . . . all could be taken as proofs of disloyalty to the state" (Salbi 2005:80). On the contrary, the Iranian government takes women's revealing their bodies, or bad-hijabi, as a moral transgression dictated by the decadent West. For them, "veiling is a woman's protection," and those who wear Western dress are taken as "U.S. LACKEYS" (Nafisi 2003:27). Here, the duty of preserving order is fulfilled by a militia unit called "the Blood of God," and "they patrol the streets to make sure that women . . . wear their veils properly, do not wear makeup, do not walk in public with men who are not their fathers, brothers or husbands" (Nafisi 2003:26). Notwithstanding their different objectives, the strategies of physical contaminations and social governmentality in the two cases cited above are very similar. In both examples, clothing functions as a disciplinary tactic to subjugate women and propagate the ideologies of the patriarchal hegemon.

Sultana and al-Sharif's narratives resonate with examples of mandatory veiling. Much like Nafisi's notion of Iranian women's invisibility, Sultana complains that forced veiling intrudes Saudi female subjects' personal territories and stamps them as "non-persons" as they become "hidden by the veil and firmly controlled by ... stern patriarchal society" (Sasson 1992:23). A similar disciplinary committee fulfills the strategic role of maintaining order by surveilling female subjects' social behavior. In Sultana's limned world, it is the "self-proclaimed Public Morality Committee" or the committee of "the Propagation of Virtue and the Prevention of Vice" that roams the streets to impose veiling on women, prohibits them from deveiling, and arrests those who openly flout established ethical and cultural norms (Sasson 1992:114-182). The enforcement begins as soon as a little girl's first menses appears - a moment that marks her irreversible transformation from childhood innocence into adulthood. The child is then compelled to don her veil and abaaya-i.e., a long, thick and black cloak to cover the whole body-lest she deviates from Islamic law (Sasson 1992:83).

In a similar way, al-Sharif (2017:46) describes the forced imposition of hijab on women by "Wahhabi-Salafi militancy, which promotes a fundamentalist reinterpretation of Islam", as a governmental intervention in the private sphere of a Saudi woman's life which occasions the formation of two different personas. This extremist discourse encourages full veiling of the female body by preaching that, "the whole of the woman - her body and her voice - is a'ura (sinful to put on display) and should not be revealed unless there is a need for her to do so" (al- 
Sharif 2017:99). It proclaims that veiling works "as a container for the entire body, without exception, and it should not be incensed or perfumed" (al-Sharif 2017:100), otherwise the woman would be considered as an adulteress. Within this discourse, veiling does not restrict women, but honors them and gives them dignity; and, by fully covering themselves, women will not only preserve themselves but also "protect society from the emergence of corruption and the spread of immorality" (al-Sharif 2017:99-100).

Sultana and Al-Sharif continue to describe a more horrible form of physical contamination: female genital mutilation. The "barbaric custom," according to Sultana, is performed on women a few weeks before they are wed or after their first menses appears. In describing the traumatic experience of her sister Nura's circumcision, Sultana narrates,

Nura, nude from the waist down, was held by four women on a bedsheet that had been spread on the ground. The oldest of the women raised her hand in the air; with horror Nura saw that she had a razor-like instrument in her hand. Nura screamed. She felt a sharp pain in her genital region. Dizzy with shock, she was lifted in the air by the women and congratulated on her coming of age. Thoroughly frightened, she saw blood pouring from her wounds ... [T]here was unbearable pain and much blood ... [H]er entire external genitalia had been removed and that, for sure, the sex act would always result in tearing, pain and bleeding. (Sasson 1992:160-1)

Al-Sharif (2017:56) recounts a similar personal agony of her own upper part of clitoris being cut with blunt and dull scissors which "caused lifelong deformities on the most intimate part of" her body. In the common Pharaonic circumcision, the girls' clitoris and labia are completely removed, and " $[t]$ hen the vaginal opening is stitched shut to leave only a small opening for the exit of menstrual blood" (al-Sharif 2017:56). This horrible tradition is practiced to protect the female subject from "deviant" and lustful behavior. The "genital mutilation" of women, however, leaves them disfigured, helpless, frustrated and psychologically wounded. In both incidents, circumcision works as a punitive tactic intended to control women and forestall their sexual immorality. Having one's most private part of her body meddled with in such a brutal way leaves a heightened sense of violation and contamination.

In illustrating similar physical contamination of self, Nafisi (2003:33) makes a direct analogy between the appropriation of some women's lives in Iran to the desperate truth of Lolita's story, "the confiscation of one individual's life by another" [italics original], and protests against the way men of the state try to shape women "according to their own dreams and desires". Throughout these memoirs, women experience enforced corporeal exposures that leave them with feelings of indignity and humiliation. A woman's life in these countries "is like having sex with a man you loathe . . . if you're forced into having sex with someone you dislike, you make your mind blank--you pretend to be somewhere else, you tend to forget your body, you hate your body" (Nafisi 2003:329). This is what women like Sultana, Nafisi, Salbi and al-Sharif do in their countries: 
dreaming, planning and pretending to be somewhere else. To use Goffman's terminology, the women experience "situational withdrawal" as they constantly, but consciously, curtail involvement in interactional events in desperate attempts to experience and see events "in a perspective not employed by others present" (Goffman 1961:61).

Other highly contaminative and common forms of physical exposure take place within the public sphere of the society, both in disciplinary institutions such as schools, universities, hospitals and prisons and in somewhat neutral public places like airports, streets, parks and coffee shops, where female subjects suffer the humiliation of enforced corporeal examination. A recurrent pattern that all the autobiographical narrators complain about is regular traumatic invasions of their personal space and their extended self at public domains. Al-Sharif relates that at the beginning of every school day, the female students were asked to line up in queues to be inspected by the teachers. The inspection was conducted to check students' nails, hair and clothing. Unexpected inspections of their bags and possessions were also very common. Any forbidden items such as "a lipstick, a comb, or a mirror . . . or even an outside book, . . . or a cassette tape or a photograph" would be confiscated (al-Sharif 2017:68). The search and seizure of the individuals' personal objects-i.e., their "possessional territory"-in Goffman's parlance, is profoundly perturbing and menacing, because the subject's possessional territory constructs part of his or her self-identity. In another illustrative example, Nafisi's daughter relates the story of such a traumatic invasion of their personal space in the classrooms:

That day in the middle of her last class-science-the principal and the morality teacher had barged in and told the girls to put their hands on their desks. The entire class had been escorted out of the classroom, without any explanation, their schoolbags searched for weapons and contraband: tapes, novels, friendship bracelets. Their bodies were searched, their nails inspected. One student . . . was taken to the principal's office: her nails were too long. There, the principal herself had cut the girl's nails, so close that she had drawn blood ... The morality teacher stood beside her, discouraging other students from approaching. For Negar, the fact that she couldn't even go near and console her friend was as bad as the whole trauma of the search. She kept saying . . . I hate myself, I hate myself. (Nafisi 2003:58-59)

Long and polished nails are symbolic of the girls' autonomy, and the principal's act of cutting them deeply is not only removing signs of social agency but also displaying complete control over the female subjects' sheath, personal and possessional territories. Likewise, in the examples cited above, appropriation of an individual's possessions and deliberately damaging and defiling them in the name of security/morality examinations are "punishment" techniques strategically used to humiliate the claimants and weaken their will towards resistance-a strategy that is initially exercised in wider strata of the society, and then extended to the private spheres insofar as the personal becomes political. An analogous exposure in Salbi's narrative can be found in the way the Mukhabarat penetrate 
the private reserve of the people without official search warrant. Such random and unprotestable invasions are often accompanied by confiscation of personal objects, and in some cases, like Salbi's mother, of the personal and national identity papers under the pretext of her being of Shia and Iranian origin. Thus, confiscation and concealment of individuals' possessional territory is used as a way of curtailing their agency and diminishing their sense of self. Though properly distinct, in the case of Salbi's mother, physical contamination is accompanied with both biographical and social contamination as they are both reduced to corporeality.

More extreme examples of corporeal exposure include interpersonal contamination of women and little girls. Sultana's brother and his friends regularly buy and rape young girls "no more than eight years old" (Sasson 1992:88). Al-Sharif relates stories of women and little girls being sexually molested by their male drivers. Nearly every woman she knows "has been harassed by a driver" (al-Sharif 2017:9). More glaring examples cited by al-Sharif (2017:183) include "stories of women who are starved, stabbed, burned, kicked out of their houses, and even locked in psychiatric institutions by male family members" as victims of "honor killings". Salbi (2005:68) similarly exposes to us how the Mukhabarat raped women on videotapes to blackmail them "into informing on family members". Nafisi (2003:48) recounts Nassrin's Humbert-like pious uncle who "had sexually abused her when she was barely" the same age as Lolita. It grieves Nassrin to remember how "his hands had wandered over her legs, her whole body" as they sat side by side when he was helping her with Arabic and math. More blatant, yet controversial examples cited by Nafisi (2003:212) include intrapersonal contamination of female prisoners in jails where virgin prisoners are "repeatedly raped" and forced to marry "the guards, who would later execute them," in order to increase the punishment. Sanaz, one of Nafisi's female students, was about to receive a similar treatment when she and five of her girlfriends who had gone for a two-day vacation to a villa by the Caspian Sea were arrested by the Revolutionary Guards "for infractions in matters of morality" (Nafisi 2003:73). The morality squads, as we are told, jailed all of them

in a small, dark room, which they shared the first night with several prostitutes and a drug addict. Their jail wardens came into their room two or three times in the middle of the night to wake up those who might have dozed off, and hurled insults at them. They were held in that room for forty-eight hours. Despite their repeated requests, they were denied the right to call their parents. Apart from brief excursions to the rest room at appointed times, they left the room twice-the first time to be led to a hospital, where they were given virginity tests by a woman gynecologist, who had her students observe the examinations. Not satisfied with her verdict, the guards took them to a private clinic for a second check . . . The girls were then given a summary trial, forced to sign a document confessing to sins they had not committed and subjected to twenty-five lashes ... [For Sanaz,] the physical pain had been more bearable than the 
indignity of the virginity tests and her self-loathing at having signed a forced confession. [italics my emphasis] (Nafisi 2003:72-3)

Here, even though the forced corporeal exposure and interpersonal contact is not as severe as violent rape, the nature of the contamination - unwanted touching and involuntary exposure of private body parts - is highly deleterious and regulating. When al-Sharif is similarly and wrongly imprisoned by the morality committee for her unconventional act of driving, her body is forced into contact with filth of both a visual and an olfactory nature. She is forced to share a small, damp, closetlike and diaper-smelling cell with twelve inmates whose sweat "had not been scrubbed off in a long time" (al-Sharif 2017:31-2). Al-Sharif (2017:242) graphically describes the way she was exposed to an "overwhelming stench of cooked food, stale sweat, and human waste," an abundance of cockroaches and the brightness of the light that prevented her from sleeping sufficiently. The direct exposure of an individual to human waste, as evidenced by Sanaz and al-Sharif, not only leaves the female subjects with horrible feelings of disgust, humiliation, shame, helplessness and rage, but also, is "physically and symbolically a highly contaminative act, demonstrating disrespect and contempt for the other, and violating her/his territory of the self along various sensory dimensions" (AllenCollinson 2009:59). In both cases, the contamination is conducted to regulate individual irregularities and maintain social stability.

Yet, of the untoward violations of the self-e.g., physical exposure of the body, forced communal sleeping and the use of sleep deprivation-illustrated in the above examples, there is also the violation of the informational and conversational preserves. Through individual confessions and examinations like virginity tests, the female subjects are compelled to expose discreditable facts and feelings about themselves that are normally concealed not only from examiners but also from their own families. The most typical example of such a violation of the informational preserve is provided with regards to Salbi's mother's ethnic background, the revelation of which not only disturbs her own social status but also affects her family's daily life. Another example includes the "sharp-tongued gossip" about al-Sharif's clandestine relationship with a male colleague. In both examples, the female subjects struggle to escape the subsequent public humiliation. In liberatory attempts, Salbi's mother tries to commit suicide and alSharif escapes into an obviously incompatible marriage with a pious man. What mattered to both, however, was to stop the growing humiliation brought about by violation of their informational preserve. Hence, when al-Sharif's father objects to her marriage decision, she replies "I am willing to have a man trample my dignity if it silences the girls who are slandering my reputation every day" (al-Sharif 2017:174).

Similar informational exposures are also occasioned by the violation of individuals' possessional territories - i.e., policing of the items female subjects possess such as bags, pockets, identity documents that they want to keep out of view. The most spectacular examples of such exposures come to us from the narrators' memories of university or school days. Nafisi, Salbi and al-Sharif recount how they similarly became objects of curiosity and were thus subject to 
routine inspections by the governmental officials. First, their clothes would be checked: the color, the length, the thickness and the form. Then the content of the bags, their makeup, the size of the rings and "their level of attractiveness" (Nafisi 2003:29). In such instances, the informational preserve is extended to what the female narrators are wearing or doing in the presence of others, i.e. to their body's sheath and their current behavior. Trespassing, touching, looking and talking are hence some of the ways through which territories of the self are shown to be encroached on by the examiners. It is noteworthy that the narrators place informational contamination into the same order as the physical and interpersonal invasion of one's body within the claimed space. Al-Sharif describes a striking example of such coercive control and micro-regulation that happened to her when she was illegally arrested for driving while female, and protests against the ubiquity of the intrusions that aim at diminishing the self. After confiscating her bags, ID and phone, the guard at the prison asks her to take off her clothes to be examined. As she bitterly recollects, "[s]ubmitting to this examination, bending over to have this strange prison guard with her gloved hands check the most intimate parts of me was the most humiliating thing I had ever experienced" (alSharif 2017:29). In like manner, Sultana and Nafisi rail against similar routine invasions of female bodies at the gates of the schools and universities. On one occasion, for instance, as Nafisi (2003:168) recounts,

They searched us from head to foot and of the many sexual molestations I have had to suffer in my life, this was among the worst. The female guard told me to hold my hands up, up and up, she said, as she started to search me meticulously, going over every part of my body. She objected to the fact that I seemed to be wearing almost nothing under the robe . . . She took a tissue and told me to rub my cheeks clean of the muck I was wearing. I explained that I wore no muck. Then she took the tissue herself and rubbed it against my cheeks, and since she did not achieve the desired results ... [S] he rubbed it even harder, until I thought she might be trying to rub my skin off.

Here, much like al-Sharif's example, Nafisi is compelled to divulge information about her body and history. Both incidents demonstrate that the invasion is not limited to the possessional preserve and the personal space but is extended to the female body's sheath. The ritual of inspection contaminates female subjects' corporeal preserve, causing feelings of humiliation, rage and resistance.

And last but not least is the annihilating control of the patriarch over the female subjects' conversational preserve in Sultana, Nafisi and al-Sharif's narratives. None of the women in these stories are morally allowed to carry out a conversation with the un-mahram men-i.e. those who are not close family relatives such as father, brother, uncle, or a son whom they can marry (al-Sharif 2017:7) — even if the men wish to have one with them. The observation of this religious law is monitored at the social level by the Public Morality Committee in Iran and, with similar methods, by the Commission for the Promotion of Virtue and the Prevention of Vice in Saudi Arabia. These religious groups, according to 
al-Sharif (2017:233-4), "are like an unmarked army, invisible and yet everywhere all the time ... They patrol malls and markets to make sure" religious laws are not violated by women by conversing with un-mahram men.

A distinctive feature of all the stories on different forms of contamination is that each exhibits to an intense degree many items in a family of attributes that can be inferred as "common characteristics" of the ruling governments, which the narrators aim to depict. All modalities of social contamination are systematically administered in all the narratives. A deeper look into their intricate use of the various female characters and recurrent motifs to relate accounts of the Middle Eastern women's life experiences reveals a suggested pattern that encourages movement from defenseless passivity to actively overthrowing the existing micropowers. Freedom from such physical, biographical and social contamination acts as a strong incentive for Sultana, Nafisi, Salbi and al-Sharif, as well as their female companions, to similarly create special spaces of their own-viz., Lively Lips club, female reading group, Women for Women International organization and Women2Drive group, respectively. Such creatively formed private localities make it possible for the subjugated women to relax, step out of the socially enforced character, invert the power relations, and re-claim their possession over personal spaces. Through these spaces, the subordinated subjects resist "against the tyranny of time and politics" that has "confiscated, driven underground, [and] taken away" from them "the most extraordinarily ordinary instances of life" such as love, music, art and literature (Nafisi 2003:6). The created spaces render the female subjects a temporarily unaffected backstage in which they perform "in a disembodied state of suspension," revealing to each other not only "their secrets, their pains and their gifts" but their experiences of operating modalities of contamination and points of confrontation. These localities become places of "transgression," sanctuaries and "self-contained universe[s]" that allow suppressed facts to reappear and "the reality of black-scarved" to be mocked (Nafisi 2003:6); it is in these safe spaces that, according to Nafisi (2003:338), "the right to free access to imagination" is granted; and finally, it is here, in their works, that the existing practices of governmentality are constantly interrogated by the subjugated women.

\section{Conclusion}

This article conducted a micro-physics study of Middle Eastern women's life narratives by using Goffman's theories of the "territories of the self" and modalities of their contamination in order to examine the operating strategies of governmentality on the female body. The disciplinary societies portrayed in the selected life testimonials are very much like Goffman's "total institution" in which all territories of the female subject's self are strategically contaminated in the interface between institutions and female bodies. Sultana, Nafisi, Salbi and alSharif limn similar worlds wherein women's territories of the self are subject to close surveillance and regular invasion. In their narratives, the Middle Eastern female subject is constantly monitored, and her gestures and behavior are continuously recorded and regulated. Throughout the narratives, women's 
informational preserve, physical and interpersonal territories are shown to be constantly and similarly intruded on by their respective communities. Individual stories of how each of the territories are occupied by the hegemonic power, and of the subjugated women's responding strategies abound. Of the three modes of violations, however, physical contamination-such as mandatory veiling/deveiling, corporeal exposure, forced exposure to dirt and appropriation of personal possessions - proves to be the most common. Taken together, the individual accounts of such intrusions and the subjects' subsequent struggles to reclaim the lost territories help to define the depths of the Middle Eastern female subjects' common yet singular experiences of woes and grief for their encroached possessions. In these memoirs, the authors imagine other possible arrangements of personal space.

The particular focus on the micro-physics of discipline in reading the subjugated women's life stories has also accentuated the defensive tactics on the part of claimants, whose territories of the self are constantly encroached and curtailed, against mortification practices. This means that the subjugated women are persistently emboldened by each other to destabilize the operating mechanism of power. In practice, by creatively making a space of their own, through the unorthodox act of documenting their life experiences, the female subjects disrupt the flow of contamination and distance themselves from mortification practices that constantly aim at discursive subjugation of women by collectively repressing, colonizing and diminishing their subjectivity. As the prescribed subordinates, these women thus profane the superordinate and challenge the totality of the disciplinary institution whose fullest realization heavily relies on the condition that the subjects cannot really respond to an assault. Thus, it would be helpful to read Middle Eastern women life narratives as confessional diaries of their daily confrontations with micro-physics of discipline; and, as creative works that intervene in the context of a socio-politically discursive moment to bring about a change.

\title{
Acknowledgment
}

This research is supported by the Short Term Grant (304/PHUMANITI/6315300) provided by Universiti Sains Malaysia. I would also like to thank the anonymous reviewers of IJAES for their useful feedback on an earlier version of this article.

\author{
Moussa Pourya Asl \\ School of Humanities, Universiti Sains Malaysia \\ Email: moussa.pourya@usm.my
}

\footnotetext{
1 The radical social implications of Goffman's work is further reinforced in the connotative definition of "total institutions" as barriers created to restrain, control and regulate social intercourse, and in the metaphorical usage of the term colonization as "standard alignment" - that is a point of reference to demonstrate the tension between two worlds (Goffman 1961: 4-63).
} 
References

Al-Sharif, Manal. (2017). Daring to Drive. London: Simon \& Schuster. Allen-Collinson, Jacquelyn. (2009). 'Intimate intrusions revisited: A case of intimate partner abuse and violations of the territories of the self'. Qualitative Sociology Review, 5 (1): 50-69.

Ameri, Firouzeh. (2012). Veiled Experiences: Rewriting Women's Identities and Experiences in Contemporary Muslim Fiction in English. Unpublished $\mathrm{PhD}$ Thesis, Murdoch University, Murdoch, Australia.

Asl, Moussa Pourya. (2019). 'Leisure as a space of political practice in Middle East Women life writings.' GEMA Online ${ }^{\circledR}$ Journal of Language Studies, 19 (3):43-56. doi:10.17576/gema-2019-1903-03

Asl, Moussa Pourya. (2018). 'Practices of counter-conduct as a mode of resistance in Middle East women's life writings'. 3L: Language, Linguistics, Literature ${ }^{\circledR}, 24$ (2): 195-205. doi:10.17576/3L-2018-2402-15

Bahramitash, Roksana. (2005). 'The war on terror, feminist Orientalism and Orientalist feminism: Case studies of two North American bestsellers'. Critique: Critical Middle Eastern Studies, 14 (2): 221-235. doi:10.1080/10669920500135512

Batmanghelichi, Kristin Soraya. (2017). '[Review of the book Foucault in Iran: Islamic revolution after the enlightenment, by Behrooz Ghamari-Tabrizi, University of Minnesota Press, 2016, 272pp., \$27.00 US]'. Journal of the Society for Contemporary Thought and the Islamicate World, (April, 2017): 1-8.

Campbell, Charles. (2019). 'The captivity narrative and East-West understanding in Aboulela's The Kindness of Enemies." International Journal of Arabic-English Studies, 19 (1): 53-70. doi: 10.33806/ijaes2000.19.1.3

Chan-Malik, Sylvia. (2011). 'Chadors, feminists, terror: The racial politics of US media representations of the 1979 Iranian women's movement'. The ANNALS of the American Academy of Political and Social Science, 637 (1): 112-140.

Dabashi, Hamid. (2006). 'Native informers and the making of the American empire'. Al-Ahram Weekly, 797: 1-7.

Death, Carl. (2016). 'Counter-conducts as a mode of resistance: Ways of "Not Being Like That” in South Africa'. Global Society, 30 (2): 201-217. doi:10.1080/13600826.2015.1133566 
Foucault, Michel. (1980). Power/Knowledge: Selected Interviews and Other Writings, 1972-1977 (Colin Gordon Ed.). New York: Pantheon.

Foucault, Michel. (1986).'Of other spaces'. Diacritics, 16 (1): 22-27.

Foucault, Michel. (1995). Discipline and Punish (Alan Sheridan, Trans.). New York: Vintage.

Goffman, Erving. (1956). The Presentation of Self in Everyday Life. Edinburgh: University of Edinburgh.

Goffman, Erving. (1961). Asylums: Essays on the Social Situation of Mental Patients and Other Inmates. Garden City, New York: Anchor Books, Doubleday \& Company, Inc.

Goffman, Erving. (1971). Relations in Public: Microstudies of the Public Order. New York: Basic Books, Inc.

Goffman, Erving. (1983). 'The interaction order: American sociological association, 1982 presidential address'. American Sociological Review, 48 (1): 1-17. doi:10.2307/2095141

Grogan, Christine. (2014). 'Lolita revisited: Reading Azar Nafisi's reading Lolita in Tehran: A memoir in books'. Women's Studies, 43 (1): 52-72. doi:10.1080/00497878.2014.852422

Hasan, Md Mahmudul. (2015). 'Seeking freedom in the "Third Space" of diaspora: Muslim women's identity in Aboulela's Minaret and Janmohamed's Love in a Headscarf'. Journal of Muslim Minority Affairs, 35 (1): 89-105.

Leib, Robert S. (2017). 'Spaces of the self: Foucault and Goffman on the microphysics of discipline'. Philosophy Today, (March 2017): 189-210. doi:10.5840/philtoday2017321153

Moore, Lindsey. (2012). 'Voyages out and in: Two (British) Muslim women's bildungromane'. In Rehanna Ahmed, Peter Morey, and Amin Yaqin (eds.), Culture, Diaspora, and Modernity in Muslim Writing, 68-84. New York: Routledge. 68-84.

Nafisi, Azar. (2003). Reading Lolita in Tehran: A Memoir in Books. New York: Random House

Naghibi, Nima. (2007). Rethinking Global Sisterhood: Western Feminism and Iran.: Minneapois, Minnesota: University of Minnesota Press.

Naghibi, Nima. (2017). 'Exilic-Diasporic life writing and human rights: A diasporic Iranian perspective'. a/b: Auto/Biography Studies, 32 (2): 175177. doi:10.1080/08989575.2017.1287916

Newns, Lucinda. (2017). 'Renegotiating romantic genres: Textual resistance and muslim chick lit'. The Journal of Commonwealth Literature, (January 28, 2017 ): 1-17. doi:10.1177/0021989416686156

O'Leary, Timothy. (2008). Foucault, experience, literature. Foucault Studies, (5): 5-25. doi:10.22439/fs.v0i5.1407

Paolucci, Paul , Micah Holland and Shannon Williams. (2005). 'The Mayberry Machiavellians in power: A critical analysis of the Bush administration through a synthesis of Machiavelli, Goffman, and Foucault'. In Jennifer 
M. Lehmann (ed.), Social Theory as Politics in Knowledge, 133-203. Emerald Group Publishing Limited.

Salbi, Zainab and Laurie Becklund. (2005). Between Two Worlds: Escape From Tyranny: Growing up in the Shadow of Saddam. New York: Penguin.

Sasson, Jean. (1992). Princess: A True Story of Life behind the Veil in Saudi Arabia. London and New York: Bantam Books. 